Article

\title{
An Empirical Study on Green Innovation Strategy and Sustainable Competitive Advantages: Path and Boundary
}

\author{
Baoshan Ge ${ }^{1}$, Yibing Yang ${ }^{1}$, Dake Jiang ${ }^{2}$, Yang Gao ${ }^{2, *}$, Xiaomin $\mathrm{Du}^{3}$ and Tingting Zhou ${ }^{3}$ \\ 1 School of Management, Jilin University, Changchun 130022, China; gebs@jlu.edu.cn (B.G.); \\ jmnming@163.com (Y.Y.) \\ 2 School of Business, Dalian University of Technology, Panjin 124221, China; jiangdake@dlut.edu.cn \\ 3 Department of Economic Management, Yingkou Institute of Technology, Yingkou 115014, China; \\ dxm0304058@163.com (X.D.); ruibing125@163.com (T.Z.) \\ * Correspondence: gzm@dlut.edu.cn
}

Received: 19 September 2018; Accepted: 8 October 2018; Published: 11 October 2018

\begin{abstract}
Although green innovation strategy (GIS) is the driving force for the sustainable development of enterprises, while the strategy is implemented, an increased cost and a change in organizational routines will cause an organization to become fragile, and even affect the sustainable competitive advantages. So, the purpose of this paper is to explore the impact path of GIS on sustainable competitive advantages and the implementation boundary of GIS. To explain the impact path, we consider the concept of dynamic capabilities to be the mediator variable. To explain the implementation boundary of GIS, we systematically explore the relationships among GIS, dynamic capabilities and sustainable competitive advantages under different levels of environmental uncertainty. Based on 241 new Chinese green firms, the empirical results find that GIS helps enterprises to gain sustainable competitive advantages. However, in the process of strategy implementation, enterprises should choose appropriate methods according to different degrees of environmental uncertainty. In a low environmental uncertainty, dynamic capabilities play a full intermediary role between GIS and sustainable competitive advantages. However, in a high environmental uncertainty, dynamic capabilities have no mediating effect between GIS and sustainable competitive advantages. This study not only integrates green management theory and strategic management theory but also makes up for the deficiencies in research on these theories and has important reference value for enterprises that seek to carry out green innovation activities.
\end{abstract}

Keywords: green innovation strategy; dynamic capabilities; environmental uncertainty; sustainable competitive advantages

\section{Introduction}

Innovation can add new vitality to enterprises and is the main driving force of economic growth in various countries. However, with the development of technological innovation around the world, the economy has developed rapidly, while the ecological environment has suffered serious damage. Hence, in the field of environmental management research, increasing numbers of scholars attach importance to the study of environmental issues at the strategic level [1,2]. Only when the governments and enterprises from all countries acknowledge environmental problems and consider them in strategic decision making can they fundamentally resolve the contradiction between environmental pollution and economic growth [3]. Thus far, studying the implementation of a green innovation strategy (GIS) has been on the agenda of many scholars. In the early research on GIS, the scholars are generally concerned about the concrete implementation activities of GIS in 
enterprises such as designing green products and the procedure of distribution [4], clean technology and pollution prevention [5]. Scholars generally believe that GIS enhances the sustainable competitive advantages [6,7]. So, most scholars pay more attention to the influence factors of implementing green innovation strategy from different perspectives, including the contractor's driving force [8] ethics orientation [9], the supplier's influence [10] and even all the whole stakeholder's influences [11]. Nevertheless, although the implementation of GIS helps enterprises to gain competitive advantages, the "key path" of strategy implementation and whether it is restricted by different situations to produce different results are unclear, and these pivotal issues are not clearly understood. Some scholars have pointed out that the implementation of GIS could increase the costs of enterprises due to green investment, which is mainly reflected in the transfer of core resources such as finance from the original main business to the field of environmental protection, thus affecting the original core business of the enterprise $[12,13]$. If the enterprise cannot guarantee the effectiveness of the new organizational structure and routine during the implementation of the strategy, the implementation of the strategy may be ineffective. That is, there is a path between a GIS and sustainable competitive advantages, and it is very important to explore and examine this path.

In fact, enterprises adopting a GIS generally engage in new activities such as green product R\&D, green ecosystem reconstruction or green process management. As a result, the original structure of the organization will no longer be effective and the organization needs to realign its routine to adapt to the development of green innovation activities. However, according to strategic management theory, the organizational routine allows for a stable resource structure, and its formation is the result of the long-term accumulation of resources [14,15]. It is difficult to change organizational routines, and employees within the organization will not easily change the original working model. Hence, organizational routines cannot be changed and adjusted at all, and changes in these routines will increase organizational costs and generate considerable risks. When the external environment of the organization is very turbulent, the risk of uncertainty for the organization will increase more. If the organization does not originally have some strategic capabilities to adapt and adjust its routines, when it adopts a GIS, it will lose its original competitive advantages [16,17]. Thus, research on the relationship between a GIS and sustainable competitive advantages needs to consider a combination of different situations and different organizational characteristics, and research on the contingency perspective has considerable academic value. In other words, it is worthwhile to study in depth the systematic issues that are embedded in a specific external context, and the kind of intermediary capabilities that enterprises that adopt a GIS need to adapt to the external environment and that help them achieve sustainable competitive advantages.

Based on the focus and paradigm of the above academic research, this paper first defines a GIS and explores its relationship with all types of sustainable competitive advantages. Then, to find the critical path between a GIS and sustainable competitive advantages, this study identifies dynamic capabilities that are important capabilities needed for the implementation of a GIS by considering the characteristics of organizational routines and the strategic management capability view. As dynamic capabilities are recognized to impact the process of constructing and reconstructing organizational routines, studying this topic will have important research value for the implementation of a GIS. On the basis of a systematic review of the research status, deficiencies and arguments of dynamic capabilities theory, this paper further measures dynamic capabilities from the perspective of organizational routines Finally, we incorporate environmental uncertainty as the external context into the research framework of the paper and explore the relationships and differences among a GIS, dynamic capabilities and sustainable competitive advantages under a high uncertainty environment and a low uncertainty environment. The above studies not only explore the implementation value and applicable boundaries of a GIS from different contingency perspectives but also reveal the mechanism of dynamic capabilities and their influence path on the relationship between a GIS and sustainable competitive advantages. This paper uses data on a sample of 241 Chinese green enterprises to empirically analyze the theoretical model. The conclusions of this paper clearly reveal the implementation path of a GIS, which is 
helpful for solving theoretical disputes regarding dynamic capabilities and expanding the research paradigm of "green competitive advantages" based on analyzing different situations from the strategic perspective. This paper contributes to the development of strategic management theory and green management theory.

\section{Theoretical Background and Hypotheses}

\subsection{GIS and Sustainable Competitive Advantages}

A GIS refers to the process in which an enterprise adopts green technology or green management to improve or change its production and operation activities to achieve the goals of reducing environmental pollution, conserving resources, reducing waste and improving the environment in alignment with the external environment and the condition of the organization. When instituting a GIS, enterprises need to actively reduce their negative impact on the environment caused by their business activities and incorporate environmental responsibility into their strategic planning. A GIS can be divided into three modes: pollution prevention, product management and the use of clean technology [5]. Based on data obtained from stakeholders, scholars have summarized the motivations of and pressure on enterprises to implement a GIS, mainly including pressure from government policy, market consumer demand, suppliers and competition [18-20]. On this basis, scholars further identified government pressure and market pressure as the driving forces that cause enterprises to carry out a GIS. The former implies that enterprises lack the initiative to engage in green innovation, and governments influence enterprises' decisions to develop a GIS by formulating and implementing environmental regulations [21,22], while the latter means that customer choices in an environment of market competition, supplier cooperation and the methods used by competitors will enable enterprises to carry out a GIS [23,24]. Thus, a GIS is affected by the characteristics of enterprises, which have dual externalities [25].

Sustainable competitive advantages have been developed according to competitive advantages theory, and they refer to competitive advantages that an enterprise can have for a long time. Sustainable competitive advantages enable an enterprise to gain long-term benefits and avoid being outdone by potential competitors through strategic replication or imitation [26]. Sustainable competitive advantages are long-term competitive advantages that do not disappear as the environment changes. Most scholars have explored the source of sustainable competitive advantages from the perspective of strategic management and found that resources and capabilities were the basis of an enterprise's sustainable competitive advantages. This is especially true regarding the cultivation of dynamic capabilities, which makes enterprises constantly update their organizational routines to adapt to the environment when it is turbulent. Some scholars have considered the sociological perspective and pointed out that social responsibility, including environmental ecological protection, green product development and business ethics, can make enterprises gain sustainable competitive advantages [27]. This paper defines sustainable competitive advantages from the perspective of strategic management, and measures them with both financial indicators and non-financial indicators. The former focuses on the sales growth rate and profit growth rate of enterprise's products, while the latter focuses on customer satisfaction and customer loyalty.

To explore the relationship between a GIS and sustainable competitive advantages, scholars have studied it from multiple perspectives. For example, some scholars have pointed out that the pivotal assets used for a pollution control strategy were proprietary material assets and technologies. An environmental strategy involves redesigning the delivery process of a product or service and redesigning production processes to reduce pollution [4]. In addition, this strategy involves reprocessing raw materials and by-products to reduce pollution and to develop new processes that will further reduce pollution. Finally, improving the efficiency of production processes and reducing the costs of raw material and waste disposal can lower production costs and create competitive advantages [28]. From the perspective of green technology upgrading and process reengineering, some 
scholars have pointed out that to acquire sustainable competitive advantages, enterprises have been required to make thorough adjustments to various aspects such as technology $R \& D$, the organizational structure, the process design and human capital, and their existing R\&D, production and marketing functions were involved in this process $[29,30]$. Using green technologies such as clean technologies, is an integrated and complex organizational process that increases the complexity of production or distribution processes and requires employees at all levels of the enterprise to improve their skills. Developing green technologies internally is a systematic process based on organizational commitment, organizational learning, cross-functional integration, and the improvement of employees' skills and engagement [31,32]. According to the resource-based view [33], this process will help the organization develop a unique resource structure and a pattern that is difficult to replicate, thus helping the enterprise to gain sustainable competitive advantages. Additionally, some scholars have proposed the necessity and benefits of using a green entrepreneurial strategy based on stakeholder pressure. Scholars have emphasized that due to the increasing improvement of environmental regulation and consumers' environmental protection awareness, enterprises will face increasing numbers of constraints. Only when environmental issues are incorporated at the strategic level can organizations obtain unique sustainable competitive advantages [34]. For example, when organizations are under pressure from the government, a GIS can prevent enterprises from being punished by the government and can also help enterprises become role models in their industry. Under market pressure, with increasing awareness of green environmental protections, consumers are more likely to choose environmentally friendly products [32]. A GIS not only meets the needs of consumers but also helps an organization develop a good ethical image and obtain product differentiation advantages by selling products at high prices $[35,36]$. Enterprises with better green innovation can increase their revenue and reduce the external costs of innovation by transferring green innovation technology and knowledge [37,38]. Hence, enterprises adopting a GIS are more likely to gain sustainable competitive advantages. Accordingly, we formulate the following hypothesis.

Hypothesis 1. Enterprises with higher levels of GIS will have more sustainable competitive advantages.

\subsection{Dynamic Capabilities under Environmental Uncertainty}

Since Teece put forward the theory of dynamic capabilities, the dynamic capabilities theory has become one of the most active research areas in the field of strategic management. As an important academic concept, there is a theoretical controversy regarding dynamic capabilities to a certain extent $[39,40]$. With the development of research on dynamic capabilities, two main schools of thought have emerged [15]. The first genre is represented by scholars such as Teece and Dyer. Using the resource-based view as their theoretical basis, these scholars have systematically expounded on the logic and connotation of dynamic capabilities by referring to Porter's industrial positioning theory and dynamic strategic conflict theory. In addition, these scholars analyzed the essential attributes of dynamic capabilities by considering three aspects, the assets, path and organizational process [39], thus proposing the landmark conclusion that dynamic capabilities are generated throughout the organization's processes and are determined by the enterprise's assets and "path". Ultimately, dynamic capabilities are divided into three dimensions: coordination/integration capabilities, learning capabilities and refactoring capabilities. This stream of research on dynamic capabilities mainly focuses on the dynamic "path" from the construction of the enterprise asset structure to its reorganization, and enterprises need to constantly revise old routines and develop new ones to gain competitive advantages [41-43]. The achievements of this genre are the most recognized in the academic world [15]. The second genre is represented by scholars such as Eisenhardt and Martin, with the indirect negation of Teece's dynamic capabilities as its starting point. Based on empirical analysis, these scholars believed that Teece's dynamic capabilities are not the direct source of enterprise competitive advantages but rather have an indirect impact on competitive advantages through various "substantial capabilities" such as product R\&D capability, alliance capability, and strategic decision-making capability [40]. 
In other words, if enterprises want to gain lasting competitive advantages, they need to develop a series of substantive capabilities through objective practice [44]. Zahra et al. further examined the development of a "substantive capacity" (best practice) by considering the organizational learning perspective on the basis of their agreement with the views [45] presented above. The authors claimed that different enterprises may have the same resource structure, but this does not mean that they have the same "substantive capacity" because the different assets and status that organizations possess [39] cause them to choose different methods to increase their knowledge and ability to learn. Therefore, learning is a mediator of the relationship between the resource structure of the organization and its substantive capabilities. The characteristics of these two schools of thought are shown in Table 1.

Table 1. Characteristics of research samples.

\begin{tabular}{|c|c|c|c|c|c|}
\hline \multicolumn{2}{|c|}{ Enterprise Size } & \multicolumn{2}{|c|}{ Year Established } & \multicolumn{2}{|c|}{ Average Turnover Level in Recent Three Years } \\
\hline 1-10 people & 16.6 & 1 year or less & 16.6 & Half a million or less & 15.4 \\
\hline $11-50$ people & 24.1 & $1-3$ years & 22.8 & Half a million to 1 million & 15.8 \\
\hline $51-100$ people & 24.1 & $3-5$ years & 15.8 & 1 million to 2 million & 14.1 \\
\hline $101-500$ people & 22.0 & $5-8$ years & 21.2 & 2 million to 3 million & 12.9 \\
\hline More than 500 people & 13.3 & More than 8 years & 23.7 & $\begin{array}{l}3 \text { million to } 5 \text { million } \\
\text { More than } 5 \text { million }\end{array}$ & $\begin{array}{l}13.3 \\
28.6\end{array}$ \\
\hline \multicolumn{6}{|c|}{ Industry } \\
\hline \multicolumn{2}{|c|}{ Software and communications } & \multicolumn{2}{|c|}{10.0} & Transportation, storage and rent & 10.8 \\
\hline \multicolumn{2}{|c|}{ Manufacturing } & \multicolumn{2}{|c|}{24.1} & Finance & 9.5 \\
\hline \multicolumn{2}{|c|}{ Real estate } & \multicolumn{2}{|c|}{13.3} & Trade, wholesale and retail & 4.6 \\
\hline \multicolumn{2}{|c|}{ Energy and environmental protection } & \multicolumn{2}{|c|}{8.3} & Accommodation and catering & 19.5 \\
\hline
\end{tabular}

Note: numbers present in percentage (\%).

Thus, it can be seen that there has been a certain amount of conflict in the study of dynamic capabilities, which is mainly due to the theoretical opposition between scholars such as Teece and Eisenhardt. Some scholars put forward their own views on the theoretical disputes between the two schools of thought. These scholars believe that the study of dynamic capabilities has moved in two separate directions, which has a negative effect on enriching the theory of dynamic capabilities [46]. The academic community must address the theoretical conflict between Teece and Eisenhardt and find a reasonable way to reconcile their opinions [15]. Fortunately, regarding the nature of dynamic capabilities, scholars have reached a consensus based on resource-based view theory that these capabilities originate in the dynamic process of constructing and reconstructing organizational routines [45]. Furthermore, dynamic capabilities depend on organizational routines and are derived from the entire path of routine updates, which is complex and difficult to capture [42]. Therefore, research on the updating of organizational routines can reveal the nature of dynamic capabilities, which will also help resolve the conflicts that arise in the study of dynamic capabilities, thereby making this stream of research more valuable.

Organizational routine renewal is the result of organizational learning, which represents the evolution of knowledge in the organization [47]. Therefore, it is more meaningful to explore the process of organizational routine renewal from the perspective of knowledge. Organizational routine renewal is the same as knowledge evolution, and both have unique internal ways of updating. The study on organizational knowledge conducted by Nelson and Winter draws on the theory of evolution, in which "heredity" and "variation" are two manifestations [48]. Heredity is directional, and refers to the inheritance of the old knowledge system. In the process of organizational selection and absorption of external knowledge, the new knowledge system is based on the old knowledge system and is the result of constant revision and evolution of the old knowledge system. However, variation is non-directional, and reflects the difference between the new knowledge system and the old knowledge system. Heredity and variation are both the results of the organization's adaptation to environment. Since the renewal of organizational routines involves the selective absorption of new knowledge, there should be two ways of dealing with new knowledge and subsequently, two results. The first is to apply new knowledge to the old knowledge system and to amend and improve the inherent systems and routines, representing the process of organizational routine amendment (RA); the second is to 
create a new knowledge structure and routine on the basis of the old knowledge system based on the acquisition of new knowledge, representing the process of organizational routine creation (RC) [49]. Routine amendment and routine creation are two methods used for organizational routine renewal, which correspond to the "heredity" and "variation" of the organization's adaptation to environmental changes. In this paper, to measure dynamic capabilities, we use routine amendment behaviors and routine creation behaviors to represent routine renewal behaviors.

Therefore, revealing the role of dynamic capabilities in the relationship between a GIS and sustainable competitive advantages can be achieved by exploring the roles of the two methods of routine renewal. Routine amendment behavior that occurs during the process of green innovation represents the heredity of green knowledge, implying that the organization has absorbed and accumulated new green knowledge in a targeted manner according to the existing green knowledge base, reorganized the green knowledge system and improved an existing routine. This results in the improvement of the organization's standard process and old routine system by emphasizing a small number of changes and slow reform and paying attention to the efficiency and implementation of new green routines. In addition, routine creation behavior that occurs during the process of green innovation represents the variation of green knowledge, which indicates that the members of the organization seek change, adventure and like to experiment. The organization mainly tends to acquire new green knowledge from external customers, partners and competitors and to study new green technologies and green management models that differ from the organization's existing knowledge systems and routines [50]. Given the adventurous nature of organizational routine creation behavior, it is associated with income uncertainty and high risk. Both routine amendment behavior and routine creation behavior are affected by environmental uncertainty, and the degree of influence is very large. In a moderately dynamic market environment, the industry boundaries are clear, the participants are explicit, and the industry structure is relatively stable. At this point, the organization attempts to engage in green innovation by relying on dynamic capabilities achieved through routine renewal, which is a detailed, analyzable and stable process [40]. Therefore, the organization is capable of updating organizational routines, which can either be improved or created to enhance efficiency [51]. Based on this information, this paper proposes the following hypotheses.

Hypothesis 2. In an environment of low uncertainty, dynamic capabilities have a positive effect on sustainable competitive advantages.

Hypothesis 3. In an environment of low uncertainty, dynamic capabilities have a complete mediating effect on the relationship between a GIS and sustainable competitive advantages.

In contrast, in a rapidly changing market environment, market boundaries are blurring, successful business models are unclear, and market players (i.e., buyers, suppliers, competitors) are ambiguous and shifting. The overall industry structure is unclear and the life cycle of new technology which appears in the industry will be very short [40,52]. Therefore, it will be difficult for enterprises to obtain sustainable competitive advantages if they develop a new green technology or improve the original technological process. The benefits of green innovation strategy are short-term. Under these circumstances, effective dynamic capabilities of the organization are necessarily reflected by the simple, highly utilized, mature and stable management processes which are not complicated [53]. Organizational routines should also include simple routines that can be tailored to specific situations and can also purposefully allow for emergent adaptation. Furthermore, when the pressure of the market environment becomes intense, enterprises should choose those simple and mature "substantive capabilities" such as alliancing, strategic decision making, and knowledge brokering, as the best practices for organization, that is focusing on "choose" rather than "change". In addition, because the members of the organization become uncertain about the acquisition and use of new green knowledge, the characteristic of new organizational routines is path-dependent from the old one [49]. At this point, updating routines by engaging in new green behavior may adversely affect and misalign the 
old routines and may also make the new routines ineffective and fragile [51]. This decision-making risk under uncertainty is the main reason organizations lose their competitive advantages. Overall, in an environment of high uncertainty, enterprises should choose those simple (not complicated) and experiential routines to deal with the unpredictable outcomes. Any activities related to routine amendment and routine creation may harm the sustainable competitive advantages. Therefore, this article proposes the last two hypotheses.

Hypothesis 4. In an environment of high uncertainty, dynamic capabilities have a negative effect on sustainable competitive advantages.

Hypothesis 5. In an environment of high uncertainty, dynamic capabilities have no mediating effect on the relationship between a GIS and sustainable competitive advantages.

Figure 1 presents the overall research framework.

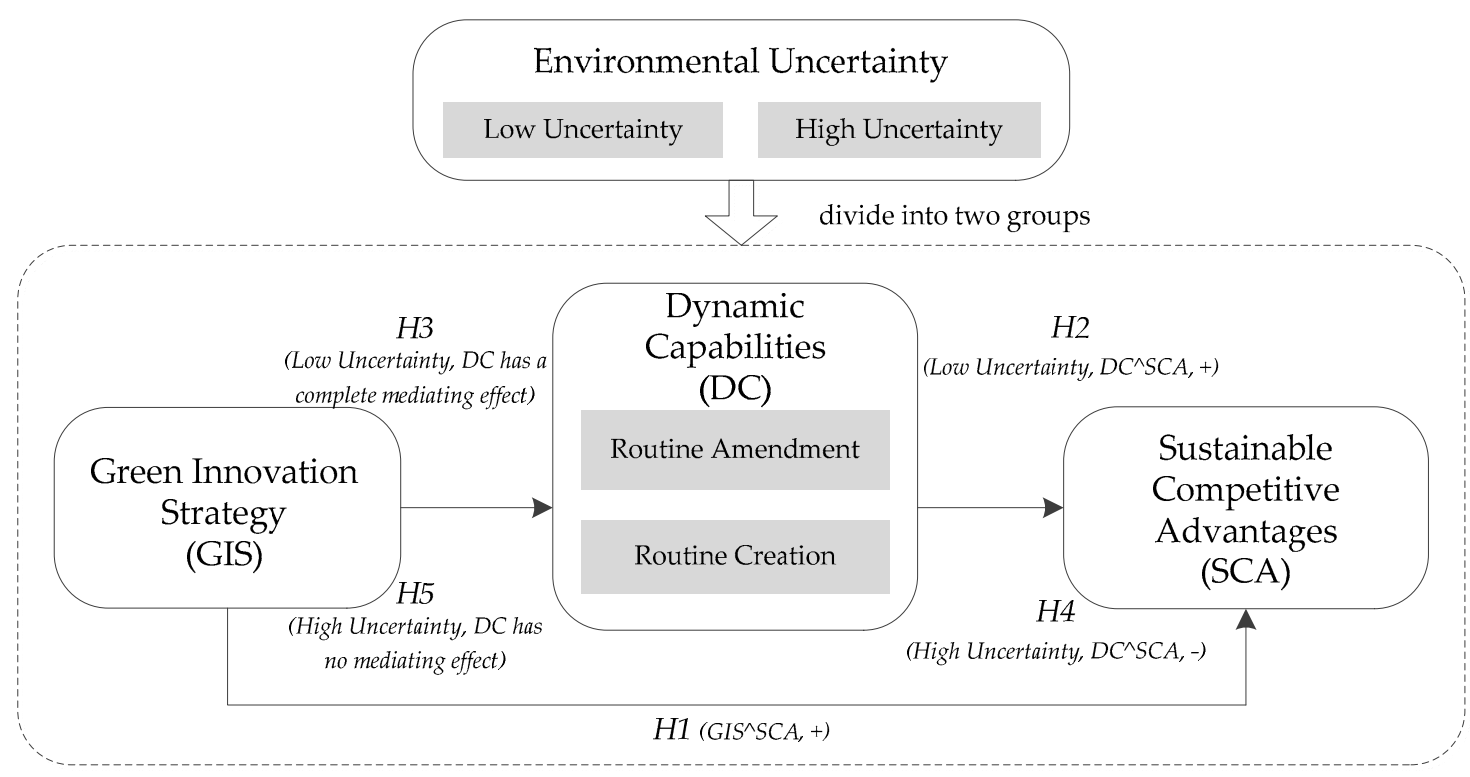

Figure 1. Research framework. Note: $A^{\wedge} B$ means the influence of $A$ to $B$.

\section{Method}

\subsection{Data and Sample Collection}

To test our hypotheses, the study conducted a questionnaire survey. First, potential samples were identified from the China Small and Medium Enterprises Statistical Yearbook and the National Small and Medium-sized Enterprises Big Data Platform, both of which provide detailed information on green enterprises. The potential samples were then screened, and green enterprises were selected as research objects. The green enterprises which are involved in the research include energy saving and environmental protection, green technological transformation, pollution control and emission reduction, green marketing and clean production. Secondly, we invited senior managers from alternative enterprises to be our informants because they receive global information on their enterprises, which makes them valuable sources for evaluating each organization's different variables. To ensure that our sample could represent a larger population, the research cities included different levels of development (i.e., capital, northern provincial capital, southern coastal cities). Thereby, we avoid the influence of regional economic development on the study. Prior to data collection, we promised participants that the detailed information they provided on their enterprises would remain confidential. Additionally, we clarified in the questionnaires that we would continue the 
investigation only when the informant agreed. Finally, the process of collecting data was started. In this critical process, we mainly took two steps to collect data. The first step was face-to-face interviews which enables managers to understand the purpose of our research. The second step was filling out the questionnaires. In this process, most managers were given some instructions and guidance about the scale items. The data collection process lasted 10 months, from September 2016 to May 2018, and 274 completed questionnaires were achieved. However, in order to ensure high-quality and validity of the questionnaires, 33 questionnaires were removed for some potential reasons (i.e., interruptions during filling, filling time is too short (less than $5 \mathrm{~min}$ ), later refused us to use for the research). In the end, 241 high-quality, valid questionnaires were used for our research. Table 1 presents the characteristics of the research samples.

\subsection{Index of Reliability and Validity}

The research tested both construct validity and convergent validity. Construct validity indicates whether the results of the evaluation's sustainable competitive advantages are related to the hypotheses. Convergent validity consists of composite reliability (CR) and average variance extracted (AVE). Table 2 presents the interpretation of the index of reliability and validity used in our research. All standards of the index are derived from quantitative statistics.

Table 2. Interpretation of the index.

\begin{tabular}{|c|c|c|c|c|}
\hline \multicolumn{3}{|c|}{ Index } & \multirow{2}{*}{$\begin{array}{l}\text { Meaning } \\
\text { It refers to the degree to which the results } \\
\text { of repeated measurements of the same } \\
\text { object are consistent. }\end{array}$} & \multirow{2}{*}{$\begin{array}{c}\text { Standard } \\
\\
>0.7\end{array}$} \\
\hline & bility & $\begin{array}{l}\text { Cronbach's } \alpha \text { Coefficient } \\
\quad(\text { Cronbach's } \alpha)\end{array}$ & & \\
\hline \multicolumn{3}{|c|}{ Kaiser-Meyer-Olkin (KMO) } & $\begin{array}{l}\text { To examine whether the factor analysis is } \\
\text { suitable for testing the validity }\end{array}$ & $>0.8$ \\
\hline \multirow{4}{*}{ Validity } & \multirow{2}{*}{$\begin{array}{l}\text { Construct } \\
\text { Validity }\end{array}$} & Factor Loading Coefficient (FLC) & \multirow{2}{*}{$\begin{array}{l}\text { The consistency between experiment and } \\
\text { theory, representing the degree that the } \\
\text { experiment could measure the theory. }\end{array}$} & $>0.5$ \\
\hline & & $\begin{array}{c}\text { Cumulative Variance Explained } \\
\text { Rate (CVER) }\end{array}$ & & $>50 \%$ \\
\hline & \multirow{2}{*}{$\begin{array}{l}\text { Convergent } \\
\text { Validity }\end{array}$} & Composite Reliability (CR) & \multirow{2}{*}{$\begin{array}{l}\text { The similarity of measurement results } \\
\text { measured by different methods in the } \\
\text { same feature }\end{array}$} & $>0.7$ \\
\hline & & Average Variance Extracted (AVE) & & $>0.5$ \\
\hline
\end{tabular}

\subsection{Measurement of Varibles}

Control variables refer to those variables other than independent variables that affect the outcome of the experiment [43]. In the empirical analysis, we used enterprise size, year established, industry, business and sales performance as control variables [54-56].

In this paper, the measurement of variables is based on exsiting literatures. To measure GIS, we used the scale proposed by Eiadat et al. [1], which includes four dimensions (See Table 3).

Table 3. Rotated factor matrixes for factor analysis of GIS.

\begin{tabular}{|c|c|c|c|c|c|c|}
\hline \multirow{2}{*}{ Factors (GIS) } & \multirow{2}{*}{$\begin{array}{l}\text { Cronbach's } \alpha \\
\text { Coefficient }\end{array}$} & \multirow{2}{*}{ KMO } & \multirow{2}{*}{ FLC } & \multirow{2}{*}{ CVER } & \multicolumn{2}{|c|}{ Construct Validity } \\
\hline & & & & & CR & AVE \\
\hline Destruction or containment of waste seriously & & & 0.950 & & & \\
\hline Capital and technology investment & & & 0.953 & & 0.970 & 0.891 \\
\hline ISO 14020 series & 0.959 & 0.875 & 0.951 & $89.137 \%$ & 0.970 & 0.891 \\
\hline Changes toward pollution prevention & & & 0.922 & & & \\
\hline
\end{tabular}

In this part, to measure dynamic capabilities, we used the scale proposed by Feldman $[57,58]$ and Miller et al. [59], which includes routine amendment (three items) and routine creation (three items) (See Table 4). 
Table 4. Rotated factor matrixes for factor analysis of dynamic capabilities.

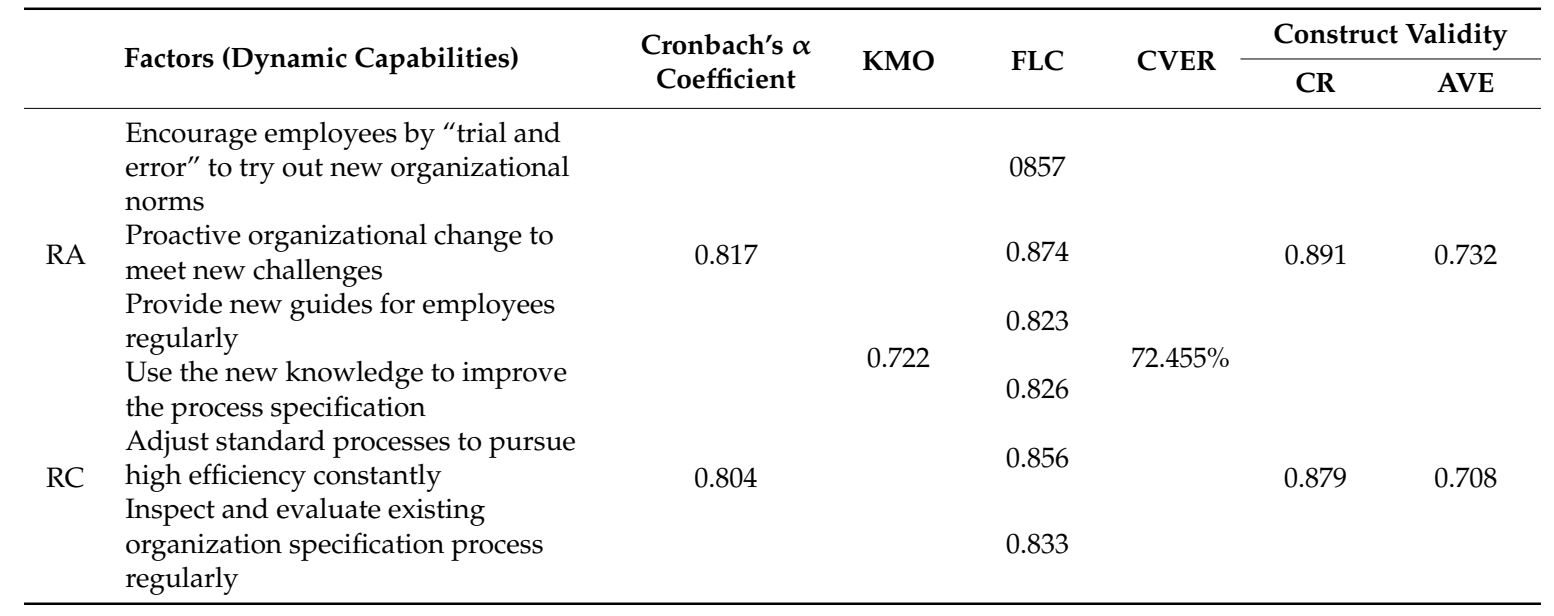

The sustainable competitive advantage is the independent variable and refers to the competitive advantages that enterprises can maintain for a long period. Following $\mathrm{Wu}$ [60], we use five items to measure sustainable competitive advantages (See Table 5).

Table 5. Rotated factor matrixes for factor analysis of sustainable competitive advantages.

\begin{tabular}{|c|c|c|c|c|c|c|}
\hline \multirow{2}{*}{ Factors (Sustainable Competitive Advantages) } & \multirow{2}{*}{$\begin{array}{l}\text { Cronbach's } \alpha \\
\text { Coefficient }\end{array}$} & \multirow{2}{*}{ KMO } & \multirow{2}{*}{ FLC } & \multirow{2}{*}{ CVER } & \multicolumn{2}{|c|}{ Construct Validity } \\
\hline & & & & & CR & AVE \\
\hline $\begin{array}{l}\text { Seek product or market information to address } \\
\text { the problems of high risk. }\end{array}$ & & & 0.821 & & & \\
\hline Seek market information to develop new projects & & & 0.865 & & & \\
\hline $\begin{array}{l}\text { Seek useful information to disentangle current } \\
\text { product or market issues. }\end{array}$ & 0.897 & 0.807 & 0.840 & $71.062 \%$ & 0.925 & 0.711 \\
\hline Seek access to new areas of product or market & & & 0.843 & & & \\
\hline $\begin{array}{l}\text { Hunt customer and competitor information to } \\
\text { improve product or market development strategy }\end{array}$ & & & 0.846 & & & \\
\hline
\end{tabular}

Moreover, environmental uncertainty has been measured using the research by Miller and Friesen [61], which includes seven items (See Table 6).

Table 6. Rotated factor matrixes for factor analysis of environmental uncertainty.

\begin{tabular}{|c|c|c|c|c|c|c|}
\hline \multirow{2}{*}{ Factors (Environmental Uncertainty) } & \multirow{2}{*}{$\begin{array}{l}\text { Cronbach's } \alpha \\
\text { Coefficient }\end{array}$} & \multirow{2}{*}{ KMO } & \multirow{2}{*}{ FLC } & \multirow{2}{*}{ CVER } & \multicolumn{2}{|c|}{ Construct Validity } \\
\hline & & & & & CR & AVE \\
\hline $\begin{array}{l}\text { Market behavior of major competitors becomes } \\
\text { increasingly difficult to predict }\end{array}$ & & & 0.907 & & & \\
\hline $\begin{array}{l}\text { Customer tastes and preferences become more } \\
\text { difficult to predict }\end{array}$ & & & 0.909 & & & \\
\hline $\begin{array}{l}\text { New technologies, new products and new services in } \\
\text { the industry emerge one after another }\end{array}$ & & & 0.905 & & & \\
\hline $\begin{array}{l}\text { The volatility of the industry in which the enterprise } \\
\text { belongs is increasingly difficult to predict }\end{array}$ & 0.917 & 0.925 & 0.916 & $67.056 \%$ & 0.934 & 0.670 \\
\hline The main contenders are becoming more adversarial & & & 0.899 & & & \\
\hline $\begin{array}{l}\text { The main competitors have occupied more market } \\
\text { shares of the enterprise }\end{array}$ & & & 0.901 & & & \\
\hline $\begin{array}{l}\text { Enterprises need to increase the degree of } \\
\text { differentiation to meet different customer needs }\end{array}$ & & & 0.897 & & & \\
\hline
\end{tabular}

\section{Empirical Results}

\subsection{Results of the General Descriptive Analysis}

Table 7 shows the descriptive statistics for each variable and the correlation coefficient matrix. As shown in the table, the mean value of the variables varies from 2 to 4 , and the standard deviation 
is relatively low, which indicates that the values of the variables fluctuate within a reasonable range. With a significance level of 0.01 , the two major researches construct a GIS and dynamic capabilities are significantly correlated with sustainable competitive advantages. For the control variables, business size, number of years established and other research constructs have a general correlation with sustainable competitive advantages. The results of the correlation analysis accord with the universal standards [62].

\subsection{Multivariate Linear Regression Models and Results}

Table 8 provides the results from the multivariate linear regression models for a GIS, RA, RC and sustainable competitive advantages. Model 1 is a benchmark model that tests the relationship between the control variables and the dependent variable (sustainable competitive advantages). According to the results of model 1, enterprise size and year established are passively related to entrepreneurial performance, indicating that a larger and older enterprise will have fewer sustainable competitive advantages. Therefore, as an enterprise develops, obtaining sustainable competitive advantages becomes increasingly difficult. Model 2 examines the influence of GIS on sustainable competitive advantages. The regression results of model 2 indicate that implementing a more comprehensive GIS is significantly correlated with sustainable competitive advantages, thus supporting Hypothesis 1. This result emphasizes that enterprises that employ a GIS achieve greater sustainable competitive advantages. Model 5 reveals that in a low uncertainty environment, dynamic capabilities have a significant positive effect on sustainable competitive advantages, thus supporting Hypothesis 2. In addition, model 8 reveals that in a high uncertainty environment, dynamic capabilities have a significant negative effect on sustainable competitive advantages, thus supporting Hypothesis 4 .

Next, we test the mediation effect, which is performed to test the relevant hypotheses using data on high uncertainty and low uncertainty. According to the mediation effect analysis process proposed by Zhao et al. (2010) [63] and the mediation test method used for multiple parallel mediator variables proposed by Preacher and Hayes (2008) [64], we use model 4 in the PROCESS plugin in SPSS, and we check the option "compare indirect effects" to confirm that there is a difference in the mediation effect of RA and RC. We select 5000 for the number of sample extractions, set the confidence interval at 95\%, and test the bootstrap median variable. It can be seen from the results shown in the following table that in a low uncertainty environment, the indirect effects of the two variables RA and RC do not contain 0 in the BootLLCI and BootULCI intervals, so the mediating effect of RA and RC on the relationship between a GIS and sustainable competitive advantages is significant. Hypothesis 3 is supported. In addition, the mediating effect of these two variables does not have a significant difference; in a high uncertainty environment, the indirect effects of the two variables RA and RC include 0 in the BootLLCI and BootULCI intervals, so the mediating effect is not significant. Hypothesis 5 is also supported (Table 9). All results of the hypotheses have be shown in Figure 2. 
Table 7. Results of descriptive statistics and correlation coefficients.

\begin{tabular}{|c|c|c|c|c|c|c|c|c|c|}
\hline \multirow{2}{*}{\multicolumn{2}{|c|}{ Variate }} & \multirow{2}{*}{$\begin{array}{l}\text { Enterprise } \\
\text { Size }\end{array}$} & \multirow{2}{*}{$\begin{array}{c}\text { Year } \\
\text { Established }\end{array}$} & \multirow{2}{*}{ Industry } & \multirow{2}{*}{$\begin{array}{c}\text { Sales } \\
\text { Performance }\end{array}$} & \multirow{2}{*}{ GIS } & \multicolumn{2}{|c|}{ Dynamic Capabilities } & \multirow{2}{*}{$\begin{array}{c}\text { Sustainable Competitive } \\
\text { Advantages }\end{array}$} \\
\hline & & & & & & & RA & RC & \\
\hline Enterprise s & & 1 & & & & & & & \\
\hline Year establis & & 0.004 & 1 & & & & & & \\
\hline Sales perform & & -0.022 & 0.065 & 0.049 & 1 & & & & \\
\hline GIS & & -0.014 & -0.05 & 0.012 & -0.069 & 1 & & & \\
\hline \multirow{2}{*}{ Dynamic capabilities } & RA & 0.03 & -0.023 & -0.03 & 0.033 & $0.163 *$ & 1 & & \\
\hline & $\mathrm{RC}$ & 0.025 & -0.097 & -0.058 & -0.018 & $0.128 *$ & $0.165 *$ & 1 & \\
\hline \multicolumn{2}{|c|}{ Sustainable competitive advantages } & -0.047 & -0.053 & 0.084 & -0.01 & $0.521 * *$ & 0.117 & 0.111 & 1 \\
\hline \multicolumn{2}{|c|}{ Standard deviation } & 1.286 & 1.429 & 2.444 & 1.844 & 1.237 & 0.861 & 0.862 & 0.761 \\
\hline
\end{tabular}

Note: * Correlation is significant at the 0.05 level. ${ }^{* *}$ Correlation is significant at the 0.01 level.

Table 8. Logistics regression analysis summary.

\begin{tabular}{|c|c|c|c|c|c|c|c|c|}
\hline & \multicolumn{8}{|c|}{ Dependent Variable: Sustainable Competitive Advantages } \\
\hline & \multirow{2}{*}{ Model 1} & \multirow{2}{*}{ Model 2} & \multicolumn{3}{|c|}{ Low Uncertainty Environment } & \multicolumn{3}{|c|}{ High Uncertainty Environment } \\
\hline & & & Model 3 & Model 4 & Model 5 & Model 6 & Model 7 & Model 8 \\
\hline Constant & -0.051 & -0.086 & -0.139 & -0.073 & -0.177 & -0.029 & -0.112 & -0.021 \\
\hline \multicolumn{9}{|l|}{ Control Variables } \\
\hline Enterprise size & -0.028 & -0.036 & 0.003 & -0.046 & -0.011 & -0.039 & -0.014 & 0.009 \\
\hline Year established & -0.034 & -0.017 & 0.017 & 0.021 & 0.044 & -0.047 & -0.035 & -0.06 \\
\hline Industry & 0.011 & 0.004 & 0.064 & 0.03 & 0.066 & -0.001 & 0.005 & -0.024 \\
\hline Sales performance & 0.096 & $0.116^{*}$ & 0.099 & 0.115 & 0.108 & 0.048 & 0.08 & 0.062 \\
\hline \multicolumn{9}{|l|}{ Main Research Variable } \\
\hline GIS & & $0.525^{* * *}$ & & $0.465^{* * *}$ & $0.269 * *$ & & $0.569^{* * *}$ & $0.537^{* * *}$ \\
\hline RA & & & & & $0.244^{* *}$ & & & $-0.202^{* *}$ \\
\hline $\mathrm{RC}$ & & & & & $0.231^{* *}$ & & & $-0.177 *$ \\
\hline Adjusted R2 & -0.007 & 0.27 & -0.021 & 0.192 & 0.309 & -0.029 & 0.297 & 0.348 \\
\hline$\triangle R 2$ & & 0.275 & & 0.212 & 0.124 & & 0.321 & 0.059 \\
\hline F change & 0.607 & $90.373^{* * *}$ & 0.407 & $30.961^{* * *}$ & $10.577^{* * *}$ & 0.155 & $55.319 * * *$ & $5.522 * *$ \\
\hline
\end{tabular}


Table 9. Results of mediation effect.

\begin{tabular}{|c|c|c|c|c|}
\hline \multicolumn{5}{|c|}{ Low Uncertainty Environment } \\
\hline \multicolumn{5}{|c|}{ Direct Effect: GIS $\rightarrow$ Sustainable competitive advantages: 0.1714} \\
\hline \multicolumn{5}{|c|}{ Indirect Effect: GIS $\rightarrow$ Sustainable competitive advantages } \\
\hline & Effect & Boot SE & BootLLCI & BootULCI \\
\hline Total Indirect Effect & 0.1178 & 0.0320 & 0.0621 & 0.1877 \\
\hline \multicolumn{5}{|l|}{ Mediate Variable } \\
\hline RA & 0.0702 & 0.0299 & 0.0199 & 0.1370 \\
\hline $\mathrm{RC}$ & 0.0476 & 0.0222 & 0.0112 & 0.1004 \\
\hline$(\mathrm{C} 1)$ & 0.0226 & 0.0418 & -0.0576 & 0.1086 \\
\hline \multicolumn{5}{|c|}{ High Uncertainty Environment } \\
\hline \multicolumn{5}{|c|}{ Direct Effect: GIS $\rightarrow$ Sustainable competitive advantages: 0.3159} \\
\hline \multicolumn{5}{|c|}{ Indirect Effect: GIS $\rightarrow$ Sustainable competitive advantages } \\
\hline & Effect & Boot SE & BootLLCI & BootULCI \\
\hline $\begin{array}{l}\text { Total Indirect Effect } \\
\text { Mediate Variable }\end{array}$ & 0.018 & 0.0137 & -0.0053 & 0.0494 \\
\hline RA & 0.0128 & 0.0115 & -0.0046 & 0.0434 \\
\hline $\mathrm{RC}$ & 0.0051 & 0.0091 & -0.0107 & 0.0266 \\
\hline (C1) & 0.0077 & 0.0156 & -0.0212 & 0.0426 \\
\hline
\end{tabular}

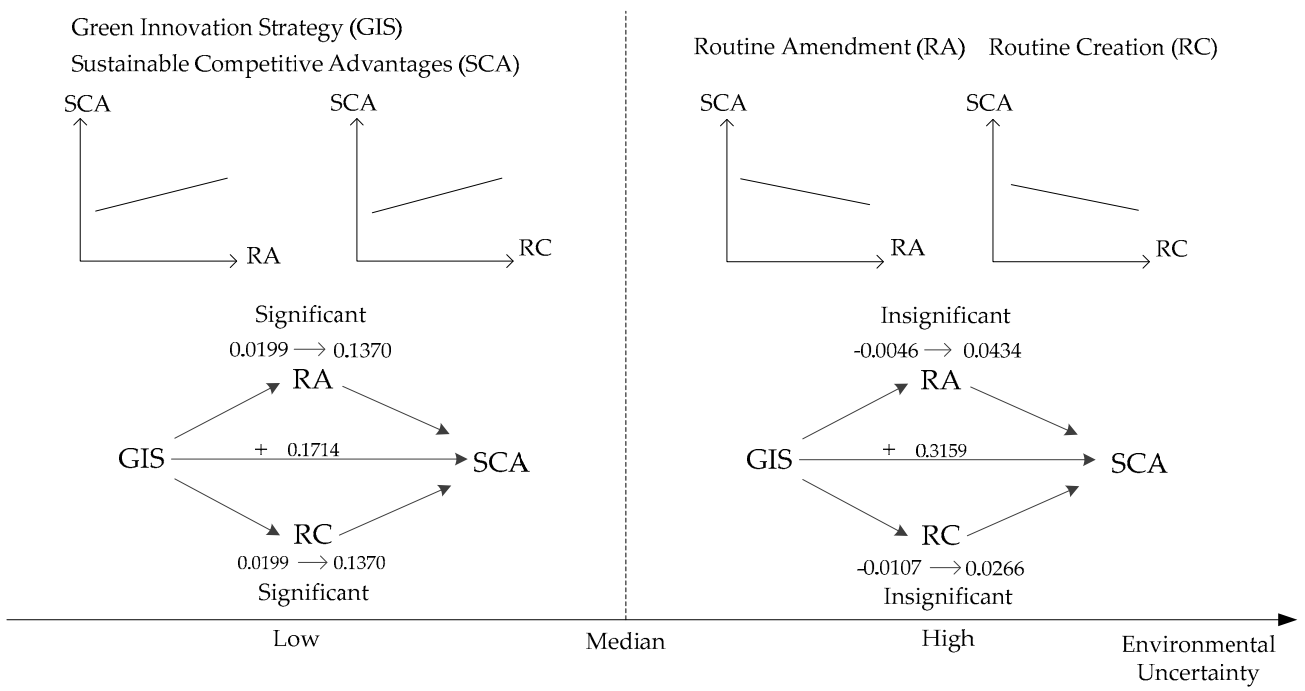

Figure 2. Result of the research hypotheses.

\section{Theoretical and Managerial Implications}

\subsection{Theoretical Implications}

This study provides the following three theoretical contributions.

First, this paper innovatively explores the impact path between GIS and sustainable competitive advantages. This analysis has important theoretical value for revealing the black box of the mechanism of GIS in organizations. Since the implementation of a GIS is a new type of green innovation activity that is based on the original organizational structure, it must involve the adjustment of organizational routines. However, in existing research, most scholars are concerned with the specific procedures or links used in the implementation of a GIS, including how to carry out green process reengineering, green technology upgrades and green management. This exploratory study ignores the important issue that changes in organizational routines can have a very large impact on organizations by causing the new organizational structure to be ineffective or vulnerable. Therefore, the renewal of organizational 
routines is a vital issue that organizations must face and address if they seek to implement a GIS. This study considers the renewal of organizational routines and introduces the research paradigm of dynamic capabilities, which makes this study more theoretical.

Second, this paper plays a vital role in resolving the divergence of the dynamic capabilities theory and improving the theory. At present, in dynamic capabilities research, scholars have debated whether dynamic capabilities have a direct effect on competitive advantages, but they have not reached a consensus. It is very difficult to reveal the essence of organizational routines because of their high level of abstraction and fuzziness, and the process creating organizational routines is the result of the evolution of organizational knowledge. Based on the theory of knowledge evolution, this paper reveals the path and mechanism of routine development by considering the effect of organizational learning, thus highlighting the process of organizational routine renewal. This research not only contributes to the reconciliation of divergent perspectives of existing dynamic capabilities theory but also fundamentally reveals the nature of dynamic capabilities, which complements and perfects strategic management theory.

Finally, this paper clarifies the implementation boundary of GIS under different levels of environmental uncertainty, and the conclusion is specific and preventive. It is concluded that GIS will have different implementation paths and results under different levels of environmental uncertainty. Especially in a turbulent external environment, enterprises implementing a GIS cannot renew their own organizational routines. The conclusion also confirms Eisenhardt's theoretical view on dynamic capabilities, which indicates that dynamic capabilities are not direct sources of competitive advantages in volatile external environments. As a result, the conclusion of this study is specific and preventive because it is based on different situations. Furthermore, incorporating contextual factors causes the theoretical model proposed in this study to have integrity and wider applicability, which plays a very important role in improving and integrating green management theory and strategic management theory, as well as expanding the applicable boundary of green sustainable theory.

\subsection{Managerial Implications}

The study of this paper has the following practical significance.

First, this paper explores the role of a GIS and its path to achieving sustainable competitive advantages, which not only helps to strengthen the confidence of enterprises that seek to carry out and effectively a GIS but also provides a clear path for the implementation of a GIS because it provides practical guidance. This study also shows that the competitive advantages of using a GIS are long term and perpetual, not short-lived. It is very important for enterprises to realize that cost increases or the short-term loss of advantages caused by the implementation of a GIS in the early stage will lead to long-term advantages. In addition, this paper reveals the implementation path of a GIS, which will help enterprise managers understand that the implementation of a GIS will change the original organizational structure and routines. Therefore, enterprise managers should pay attention to organizational routines, including establishing flexible organizational routines and constantly relying on new knowledge to make routines more diversified, thus providing the foundation for enterprises to effectively implement green activities.

Second, by considering the mechanism of a GIS in organizations, this paper considers organizational routines and introduces dynamic capabilities, which plays an important role in recognizing and cultivating the dynamic capabilities of enterprises. Enterprises can cultivate dynamic capabilities mainly in two ways: routine amendment behavior and routine creation behavior. Routine amendment behavior emphasizes the need for enterprises to specifically absorb and accumulate external knowledge and improve existing knowledge systems, which can help enterprises to constantly revise ineffective standard processes and inefficient operations by updating organizational routines; while routine creation behavior emphasizes the need for enterprises to constantly make changes, take risks and continuously acquire information from external stakeholders and create new routines that differ from those that rely on the existing knowledge system. Finally, when cultivating dynamic 
capabilities, business managers need to recognize that adjusting routines is a long-term process because routines are difficult to change, and organizations resist implementing new routines because they may become fragile [55]. Business managers can try to cultivate the organizational culture, which may potentially affect participants' cognition. At the same time, business managers need to constrain and guide the behavior of participants and standardize the organization's standardized processes, so that the organization's staff will better accept and adapt to the new routines.

Finally, this paper incorporates environmental uncertainty as a situational variable, investigates the action path and effect of a GIS on sustainable competitive advantages under different levels of environmental uncertainty, and compares the different results for these different levels. This study has great practical value by helping enterprises understand when and how to implement a GIS. The conclusion can help enterprise managers realize that context-based green innovation is more meaningful. That is, enterprise managers cannot blindly engage in green innovation, and the implementation of a GIS should be carried out in a manner that is appropriate for each specific situation. In a moderate market environment, enterprises can implement strategies by amending organizational routines and creating organizational routines, but in a volatile market environment, enterprises cannot update their organizational routines. Dynamic capabilities are not direct sources of the competitive advantages of enterprises [65]. Enterprises can appropriately slow down the implementation of a GIS, or they can engage in green innovation behavior based on mature substantive capabilities, but they should not adjust organizational routines $[31,35,66]$.

\section{Conclusions}

The main purpose of this paper is to explore the impact path of GIS on sustainable competitive advantages and the implementation boundary of GIS. To explain the impact path, we consider the concept of dynamic capabilities to be the mediator variable between GIS and sustainable competitive advantages; to explain the implementation boundary of GIS, we incorporate environmental uncertainty as a contextual variable and systematically explore the relationships among GIS, dynamic capabilities and sustainable competitive advantages under different levels of environmental uncertainty. Based on this, the paper reaches the following conclusions. First, this study finds that a GIS can help an enterprise to achieve sustainable competitive advantages. This conclusion indicates that an enterprise's GIS should be in line with new economic trends and demands. Although the implementation of a GIS is risky, the effective formulation of a GIS cannot be ignored. If a GIS is implemented effectively, it will increase the potential value of a product, enhance customer acceptance that product, and improve the brand effect and ethics of the enterprise, which will have various benefits for the enterprise. Second, this study introduces the concept of dynamic capabilities to explore the implementation path of a GIS in an organization. It is found that the essence of dynamic capabilities lies in the renewal of organizational routines, which mainly involves routine amendment behavior and routine creation behavior. This conclusion plays a crucial role in revealing the essence of dynamic capabilities. Finally, a systematic test was conducted to reveal, in depth, the relationships among a GIS, dynamic capabilities and sustainable competitive advantages under different levels of environmental uncertainty. It is concluded that in an environment with low uncertainty, enterprises need to implement a GIS through the cultivation of dynamic capabilities, which mediate the relationship between a GIS and sustainable competitive advantages; however, in a highly uncertain environment, dynamic capabilities do not mediate the relationship between a GIS and sustainable competitive advantages. In this type of environment, an organization cannot implement a GIS through routine renewal, and dynamic capabilities are not direct sources of sustainable competitive advantages. This conclusion not only reveals that the effective implementation path of a GIS needs to be selected according to different situations but also addresses deficiencies in dynamic capabilities theory and plays a vital role in promoting the development of green management theory and strategic management theory.

Although our research integrates green management theory and strategic management theory, and points out the significance and key implementation path of a GIS in the current economic 
environment, there are still some limitations. First, the sample data used in this paper are derived from Chinese green enterprises. Because the data are obtained from a single country, this means the universality of the research conclusions needs to be strengthened. In the future, the scope of the investigation of the sample should be expanded. Second, this paper conducts group testing; group testing can clearly explain the implementation conditions and the boundaries of the implementation path, but it also leads to a relatively small number of samples in each group. Therefore, the next step is to expand the sample size and use a standard deviation of \pm 1 as the grouping standard. Finally, in terms of the measurement of non-financial performance indicators of sustainable competitive advantages, this paper mainly focuses on the evaluations and responses of customers to products due to the excessive number of stakeholders involved. In fact, the evaluation of enterprise products and management models by other stakeholders is still of significance. In the future, we need to further test the value of the theoretical model proposed in this paper for studying other aspects of sustainable competitive advantages.

Author Contributions: B.G. and Y.G. proposed the conceptualization of this study. Y.Y. and T.Z. made the formal analysis. D.J. used the Methodology. Y.G. and X.D. wrote the paper.

Funding: This research was funded by the China Natural Science Foundation $(71620107001,71602016,71472071)$, Science Foundation of Ministry of Education of China (16YJC630025), the China Postdoctoral Science Foundation (2018T110227), the Liaoning S\&T Project (20170520262) and the Dalian University of Technology Fundamental Research Fund (DUT17RC(4)30.

Conflicts of Interest: The authors declare no conflicts of interest.

\section{References}

1. Eiadat, Y.; Kelly, A.; Roche, F.; Eyadat, H. Green and competitive? An empirical test of the mediating role of environmental innovation strategy. J. World Bus. 2008, 43, 131-145. [CrossRef]

2. Darnall, N.; Henriques, I.; Sadorsky, P. Adopting proactive environmental strategy: The influence of stakeholders and firm size. J. Manag. Stud. 2010, 47, 1072-1094. [CrossRef]

3. Roseland, M. Sustainable community development: Integrating environmental, economic, and social objectives. Prog. Plan. 2000, 54, 73-132. [CrossRef]

4. Stead, W.; Stead, J. An empirical investigation of sustainability strategy implementation in industrial organizations. Res. Corp. Soc. Perform. Policy 1995, 1, 43-66.

5. Hart, S.L. Beyond greening: Strategies for a sustainable world. Harv. Bus. Rev. 1997, 75, 66-76.

6. Chen, Y.S.; Lai, S.B.; Wen, C.T. The influence of green innovation performance on corporate advantage in Taiwan. J. Bus. Ethics 2006, 67, 331-339. [CrossRef]

7. Ar, I.M. The impact of green product innovation on firm performance and competitive capability: The moderating role of managerial environmental concern. Procedia-Soc. Behav. Sci. 2012, 62, 854-864. [CrossRef]

8. Qi, G.Y.; Shen, L.Y.; Zeng, S.X.; Jorge, O.J. The drivers for contractors' green innovation: An industry perspective. J. Clean. Prod. 2010, 18, 1358-1365. [CrossRef]

9. Chang, C.H. The influence of corporate environmental ethics on competitive advantage: The mediation role of green innovation. J. Bus. Ethics 2011, 104, 361-370. [CrossRef]

10. Chiou, T.Y.; Chan, H.K.; Lettice, F.; Chung, S.H. The influence of greening the suppliers and green innovation on environmental performance and competitive advantage in Taiwan. Transp. Res. Part E Logist. Transp. Rev. 2011, 47, 822-836. [CrossRef]

11. Qi, G.Y.; Zeng, S.X.; Tam, C.M.; Yin, H.T.; Zou, H.L. Stakeholders' influences on corporate green innovation strategy: A case study of manufacturing firms in China. Corp. Soc. Responsib. Environ. Manag. 2013, 20, 1-14.

12. Ghisetti, C.; Rennings, K. Environmental innovations and profitability: How does it pay to be green? J. Clean. Prod. 2014, 75, 106-117. [CrossRef]

13. Yanarella, E.J.; Levine, R.S.; Lancaster, R.W. Research and solutions: "green” vs. sustainability: From semantics to enlightenment. Sustain. J. Rec. 2009, 2, 296-302. [CrossRef]

14. Teece, D.J. Explicating dynamic capabilities: The nature and micro foundations of (sustainable) enterprise performance. Strat. Manag. J. 2007, 28, 1319-1350. [CrossRef] 
15. Peteraf, M.; Stefano, G.D.; Verona, G. The elephant in the room of dynamic capabilities: Bringing two diverging conversations together. Strat. Manag. J. 2013, 34, 1389-1410. [CrossRef]

16. Feldman, M.S. Routines as process: Past, present, and future. Organ. Routines 2016, 6, 23-46.

17. Chen, Y.S.; Lin, Y.H.; Lin, C.Y.; Chang, C.W. Enhancing green absorptive capacity, green dynamic capacities and green service innovation to improve firm performance\&58; an analysis of structural equation modeling (SEM). Sustainability 2015, 7, 15674-15692.

18. Tang, Z.; Tang, J. Stakeholder-firm power difference, stakeholders' CSR orientation, and SMEs' environmental performance in china. J. Bus. Ventur. 2012, 27, 436-455. [CrossRef]

19. Li, S.; Jayaraman, V.; Paulraj, A.; Shang, K. Proactive environmental strategies and performance: Role of green supply chain processes and green product design in the Chinese high-tech industry. Int. J. Prod. Res. 2016, 54, 2136-2151. [CrossRef]

20. Sarkar, A.N. Promoting eco-innovations to leverage sustainable development of eco-industry and green growth. Eur. J. Sustain. Dev. 2013, 2, 171-224.

21. Jaffe, A.B.; Newell, R.G.; Stavins, R.N. A tale of two market failures: Technology and environmental policy. Ecol. Econ. 2004, 54, 164-174. [CrossRef]

22. Frondel, M.; Horbach, J.; Rennings, K. End-of-pipe or cleaner production? An empirical comparison of environmental innovation decisions across OECD countries. Bus. Strat. Environ. 2007, 16, 571-584. [CrossRef]

23. Liu, Y.; Guo, J.; Chi, N. The antecedents and performance consequences of proactive environmental strategy: A meta-analytic review of national contingency. Manag. Organ. Rev. 2015, 11, 521-557. [CrossRef]

24. Ford, J.A.; Steen, J.; Verreynne, M.L. How environmental regulations affect innovation in the Australian oil and gas industry: Going beyond the porter hypothesis. J. Clean. Prod. 2014, 84, 204-213. [CrossRef]

25. Berrone, P.; Fosfuri, A.; Gelabert, L.; Gomez-Mejia, L.R. Necessity as the mother of 'green' inventions: Institutional pressures and environmental innovations. Strat. Manag. J. 2013, 34, 891-909. [CrossRef]

26. Lu, I.Y.; Kuo, T.; Lin, T.S.; Tzeng, G.H.; Huang, S.L. Multicriteria decision analysis to develop effective sustainable development strategies for enhancing competitive advantages: Case of the TFT-LCD industry in Taiwan. Sustainability 2016, 8, 646. [CrossRef]

27. Yu, C.; Zhang, Z.; Lin, C.; Wu, Y.J. Knowledge creation process and sustainable competitive advantages: The role of technological innovation capabilities. Sustainability 2017, 9, 2280. [CrossRef]

28. Ashford, N. Understanding technological responses of industrial firms to environmental problems: Implications for government policy. In Environmental Strategies for Industry: International Perspectives on Research Needs and Policy Implications; Island Press: Washington, DC, USA, 1993; pp. 277-307.

29. Newman, J.C.; Breeden, K.M. Managing in the environmental era. Columbia J. World Bus. 1992, $27,210-222$.

30. Chen, Y.S.; Chang, T.W.; Lin, C.Y.; Lai, P.Y.; Wang, K.H. The influence of proactive green innovation and reactive green innovation on green product development performance: The mediation role of green creativity. Sustainability 2016, 8, 966. [CrossRef]

31. Smart, B. Beyond Compliance-A New Industry View of the Environment; World Resources Institute: Washington, DC, USA, 1992.

32. Groenewegen, P.; Vergragt, P. Environmental issues as threats and opportunities for technological innovation. Technol. Anal. Strat. Manag. 1991, 3, 43-55. [CrossRef]

33. Barney, J.; Wright, M.; Ketchen, D.J., Jr. The resource-based view of the firm: Ten years after 1991. J. Manag. 2001, 27, 625-641. [CrossRef]

34. Ge, B.; Jiang, D.; Gao, Y.; Tsai, S.B. The influence of legitimacy on a proactive green orientation and green performance: A study based on transitional economy scenarios in China. Sustainability 2017, 8, 1344. [CrossRef]

35. Menguc, B.; Auh, S.; Ozanne, L. The interactive effect of internal and external factors on a proactive environmental strategy and its influence on a firm's performance. J. Bus. Ethics 2010, 94, 279-298. [CrossRef]

36. Hojnik, J.; Ruzzier, M. The driving forces of process eco-innovation and its impact on performance: Insights from Slovenia. J. Clean. Prod. 2016, 133, 812-825. [CrossRef]

37. Fernando, Y.; Wah, W.X. The impact of eco-innovation drivers on environmental performance: Empirical results from the green technology sector in Malaysia. Sustain. Prod. Consum. 2017, 12, 27-43. [CrossRef]

38. Montabon, F.; Sroufe, R.; Narasimhan, R. An examination of corporate reporting, environmental management practices and firm performance. J. Oper. Manag. 2007, 25, 998-1014. [CrossRef] 
39. Teece, D.J.; Pisano, G.; Shuen, A. Dynamic capabilities and strategic management. Strat. Manag. J. 1997, 18, 509-533. [CrossRef]

40. Eisenhardt, K.M.; Martin, J.A. Dynamic capabilities: What are they? Strat. Manag. J. 2000, 21, $1105-1121$. [CrossRef]

41. Dyer, J.H.; Nobeoka, K. Creating and managing a high-performance knowledge-sharing network: The Toyota case. Strat. Manag. J. 2000, 21, 345-367. [CrossRef]

42. Amit, R.; Zott, C. Value Creation in E-Business. Strat. Manag. J. 2001, 22, 493-520. [CrossRef]

43. Makadok, R. Toward a synthesis of the resource-based and dynamic-capability views of rent creation. Strat. Manag. J. 2001, 22, 387-401. [CrossRef]

44. Benner, M.J.; Tushman, M.L. Exploitation, exploration, and process management: The productivity dilemma revisited. Acad. Manag. Rev. 2003, 28, 238-256. [CrossRef]

45. Zahra, S.A.; Sapienza, H.J.; Davidsson, P. Entrepreneurship and dynamic capabilities: A review, model and research agenda. J. Manag. Stud. 2006, 43, 917-955. [CrossRef]

46. Barreto, I. Dynamic capabilities: A review of past research and an agenda for the future. J. Manag. 2010, 36, 256-280. [CrossRef]

47. Yin, H.; Knowlton, B. The role of the basal ganglia in habit formation. Nat. Rev. Neurosci. 2006, 7, $464-476$. [CrossRef] [PubMed]

48. Winter, S.; Nelson, R. An Evolutionary Theory of Economic Change; Social Science Electronic Publishing: Rochester, NY, USA, 1982; p. 32.

49. Chassang, S. Building routines: Learning, cooperation, and the dynamics of incomplete relational contracts. Am. Econ. Rev. 2010, 100, 448-465. [CrossRef]

50. Noni, I.D.; Apa, R. The moderating effect of exploitative and exploratory learning on internationalizationperformance relationship in SMEs. J. Int. Entrep. 2015, 13, 96-117. [CrossRef]

51. Everitt, B.J.; Robbins, T.W. Neural systems of reinforcement for drug addiction: From actions to habits to compulsion. Nat. Neurosci. 2005, 8, 1481-1489. [CrossRef] [PubMed]

52. Gao, Y.; Ge, B.S.; Lang, X.; Xu, X. Impacts of proactive orientation and entrepreneurial strategy on entrepreneurial performance: An empirical research. Technol. Forecast. Soc. Chang. 2018, 135, 178-187. [CrossRef]

53. Eisenhardt, K.M.; Sull, D.N. Strategy as simple rules. Harv. Bus. Rev. 2001, 79, 106-119. [PubMed]

54. Delgado-Ceballos, J.; Aragón-Correa, J.A.; Ortiz-de-Mandojana, N.; Rueda-Manzanares, A. The effect of internal barriers on the connection between stakeholder integration and proactive environmental strategies. J. Bus. Ethics 2012, 107, 281-293. [CrossRef]

55. Lin, H.; Zeng, S.X.; Ma, H.Y.; Qi, G.Y.; Tam, V.W. Can political capital drive corporate green innovation? Lessons from China. J. Clean. Prod. 2014, 64, 63-72. [CrossRef]

56. Barrales-Molina, V.; Montes, F.J.L.; Gutierrez-Gutierrez, L.J. Dynamic capabilities, human resources and operating routines: A new product development approach. Ind. Manag. Data Syst. 2015, 115, 1388-1411. [CrossRef]

57. Feldman, M.S.; Pentland, B.T. Reconceptualizing organizational routines as a source of flexibility and change. Adm. Sci. Q. 2003, 48, 94-118. [CrossRef]

58. Feldman, M.S. Past, Present, and future. In Organizational Routines: How They Are Created, Maintained, and Changed; Oxford University Press: Oxford, UK, 2016; pp. 23-46.

59. Miller, K.D.; Pentland, B.T.; Choi, S. Dynamics of performing and remembering organizational routines. J. Manag. Stud. 2012, 49, 1536-1558. [CrossRef]

60. Wu, L.Y. Applicability of the resource-based and dynamic-capability views under environmental volatility. J. Bus. Res. 2010, 63, 27-31. [CrossRef]

61. Miller, D.; Friesen, P.H. Strategy making and environment: The third link. Strat. Manag. J. 1983, 4, $221-235$. [CrossRef]

62. Tabachnick, B.G.; Fidell, L.S. Using Multivariate Statistics, 4th ed.; Allyn \& Bacon: Boston, MA, USA, 2006.

63. Zhao, X.; Lynch, J.G., Jr.; Chen, Q. Reconsidering Baron and Kenny: Myths and truths about mediation analysis. J. Consum. Res. 2010, 37, 197-206. [CrossRef]

64. Preacher, K.J.; Hayes, A.F. Asymptotic and resampling strategies for assessing and comparing indirect effects in multiple mediator models. Behav. Res. Methods 2008, 40, 879-891. [CrossRef] [PubMed] 
65. Becker, M.C. Organizational routines: A review of the literature. Ind. Corp. Chang. 2008, 13, $643-678$. [CrossRef]

66. Teece, D.J. A dynamic capabilities-based entrepreneurial theory of the multinational enterprise. J. Int. Bus. Stud. 2014, 45, 8-37. [CrossRef] 